Original Contribution

\title{
IMPROVE GERMINATION OF CAPER (CAPPARIS SPINOSA L.) SEEDS BY DIFFERENT INDUCTION TREATMENTS OF SEED DORMANCY BREAKING
}

\author{
M. R. Labbafi* , A. Mehrafarin, H. Naghdi Badi, M. Ghorbani, M. Tavakoli
}

Medicinal Plants Research Centre, Institute of Medicinal Plants, ACECR, Karaj, Iran

\begin{abstract}
Seed dormancy is a common phase of the plant life cycle; different treatments can be used for breaking dormancy. The aim of this study was to find the best treatment for breaking dormancy and improve germination of caper (Capparis spinosa L.). This study based on the completely randomized design (CRD) with 3 replications was done at research Laboratory of Medicinal Plants Institute, ACECR, Karaj, Iran. After different induction treatments containing different levels of potassium nitrate $\left(\mathrm{KNO}_{3}\right)$, $\mathrm{GA}_{3}$, soaking and soaking with runner water, sulfuric acid, thidiazuron, and benzyl amino-purine, seeds were placed in Petri-dishes and incubated in two temperature regimes, first at fixed $20^{\circ} \mathrm{C}$, and second, alternate between 20 and $30^{\circ} \mathrm{C}$. The result showed that the germination percentage and germination rate of caper increased up to $75 \%$ and 1.35 respectively when the seeds treated with sulfuric acid for 15 min, and $2000 \mathrm{ppm} \mathrm{GA} 3$ under alternate $20-30{ }^{\circ} \mathrm{C}$ temperatures. Caper seed dormancy is mainly due to the inhibitors and hard seed coat that it prevents seed germination.
\end{abstract}

Keywords: Germination rate, Germination percentage, Soaking, $\mathrm{GA}_{3}$, Potassium nitrate.

\section{INTRODUCTION}

Caper (Capparis spinosa L.) belongs to family of Capparidaceae and is said to be native to the Mediterranean region, but it is also found and cultivated on the Atlantic coasts of the Canary Islands, Morocco, Spain (Almeria, Grenada \& Balearic Islands), France (Provence) and Italy, Greece, Cyprus, Turkey, and Iran both under cultivated and rainfed conditions (1-2). Caper has been using as a medicinal and aromatic plant for a long time. Capers reduce flatulence and to be anti-rheumatic in effect. Capparis are recorded as hepatic protectors, improving liver function, arteriosclerosis, as diuretics, kidney disinfectants, and tonics, dropsy, anemia, arthritis and gout (3).

Caper plants can be propagated from seeds or stem cuttings, however, both methods present serious problems and restrictions to the commercial expansion of this crop (4). Seed dormancy is a common phase of the plant life cycle, and several parts of the seed can contribute to dormancy (5). There are basically

\footnotetext{
*Correspondence to: Labbafi M.R., Institute of Medicinal Plants, Research Complex of Iranian Academic Center for Education, Culture and Research (ACECR) P.O.Box: (Mehr Villa): 31375 369 Karaj, Iran, Email:

Mohammad1700@yahoo.com
}

two types of dormancy involving different mechanisms (6-7): embryo dormancy and coatimposed dormancy. The inability to germinate in caper seeds is unlikely to be due to embryo dormancy: a partial removal of the seed covering structures, as well as cuts or punctures through them, have been the most effective treatments in stimulating caper germination (8). Fresh caper seeds germinate readily but in low percentages $(1-2 \%)$, whereas drying of seeds induces severe dormancy, which is difficult to overcome naturally (9). As the dormancy in caper crop is due to the hard seed coat, external treatments are necessary to overcome the prevailing dormancy. The structure of the seed and the mucilage which develops when the seed is placed in contact with water could impose an effective barrier against the diffusion of oxygen to the embryo (2).

Pre-chilling, scarification, and treatments with gibberellic acid $\left(\mathrm{GA}_{3}\right)$ or nitric acid $\left(\mathrm{KNO}_{3}\right)$ are the standard procedures used to enhance seed germination of dormant seeds. To obtain higher germination (\%) in Capparis various treatments were reported, viz gibberellic acid $+\mathrm{KNO}_{3}$ (10-11), pre-treatment with Sulphuric acid $\left(\mathrm{H}_{2} \mathrm{SO}_{4}\right)(12), \mathrm{H}_{2} \mathrm{SO}_{4}+\mathrm{GA}_{3}$ (8) and warm water+chilling (13). 
LABBAFI M. R., et al.

The purpose of this study was to found methods for breaking the dormancy of caper (Capparis spinosa L.) seeds.

\section{MATERIAL AND METHODS Seed Source and Preparing}

Caper seeds (SB-MPI-1225) were obtained from National Gene Bank and Seed Collection of Institute of Medicinal Plants (IMP) in Iran and all studies were conducted at this place. During germination experiments, the seeds were surface-sterilized by $5 \mathrm{~min}$ exposure to $3 \%$ calcium hypochlorite, thoroughly rinsed with sterile distilled water and transferred to plates (14). Fifty seeds were placed on filter paper (Whatman \# 2) in $11 \mathrm{~cm}$ diameter Petridishes with four replicates per treatment in each experiment. The filter paper was moistened with $7 \mathrm{ml}$ of distilled water or test solution. After moistening, the Petri-dishes were sealed to prevent desiccation with a plastic film (Parafilm, American National Can, 101 Merntt, Greenwich, CT 06836). Each treatment was applied to three dishes. The seeds were considered germinated when the radicle was $5 \mathrm{~mm}$ or longer (15). Germination tests were conducted in controlled environment chambers (Plant growth chamber, Model GC300 LT/H, JEIO Tech Co., Ltd., Seoul, South Korea).

\section{Treatments}

+ Potassium nitrate $\left(\mathrm{KNO}_{3}\right)$ : seeds were soaked in 0.1 and $0.2 \% \mathrm{PN}$.

$+\mathrm{GA}_{3}$ : seeds were soaked in 500, 1000 and $2000 \mathrm{ppm} \mathrm{GA} \mathrm{G}_{3}$ for $72 \mathrm{~h}$ and then used to the germination test process.
+ Soaking in running water: seeds were soaked in running water for $24 \mathrm{~h}$.

+ Sulfuric acid $\left(\mathrm{H}_{2} \mathrm{SO}_{4}\right)$ : used sulfuric acid $96 \%$ for 15 and 30 minute.

+ Soaking: seeds were soaked in water for $72 \mathrm{~h}$ and then transferred to the germination test process.

+ Soaking under different temperature: seeds were put into flasks contained water and then flask put into Ben Murray (40, 50, 60 and $70 \mathrm{c}$ ) for 15,30 and 60 minute. After that germination test process occurred.

+ Thidiazuron (TDZ): is a plant growth regulator used $20 \mathrm{ppm}$ in this experiment.

+ Benzyl Amino-Purine (BAP): is a synthetic cytokinin used $20 \mathrm{ppm}$ in this experiment.

\section{Design and Statistical Analysis:}

Germination percentage was calculated as [(the number of germinated seeds)/the number of sampled seeds] $\times 100(16)$ :

The data analyzed by a one-way analysis of variance (ANOVA) using SAS version 9.1. The data were analyzed using a randomized complete design and LSD test was used to determine if there were significant $(\mathrm{p}<0.05)$ differences among treatment means and used Excel 2010 for drawing the figure.

\section{RESULT AND DISCUSSION}

The result of this study showed that the using different treatments (concentration of potassium nitrate, $\mathrm{GA}_{3}$, soaking in running water, soaking, sulfuric acid, thidiazuron and benzyl amino-purine) had the significant effect $(p \leq 0.01)$ on seed germination of caper (Table 1).

Table 1. Analyses of Variances of Germination Percentage of Capparis Spinosa L. Under Different Treatments

\begin{tabular}{cccc}
\hline S.o.v & df & Germination percentage & Germination rate \\
\hline Treatment & 34 & $13.42^{* *}$ & $0.058^{* *}$ \\
Error & 70 & 157.05 & 0.012 \\
\hline CV & - & 28.03 & 12.25 \\
\hline$* *=$ significant at $1 \%$ & & &
\end{tabular}

Sulfuric acid increased germination percentage, if it is used with other germination promote, germination will be better. Caper germination and Germination rate increased up

to $75 \%$ and 1.35 respectively, when seeds treated with sulfuric acid for $15 \mathrm{~min}$ and 2000 ppm $\mathrm{GA}_{3}$ under alternate $20, \quad 30 \quad{ }^{\circ} \mathrm{C}$ temperatures. (Table 2).

Researchers (17) investigated effects of dormancy-breaking treatments on germination in caper (Capparis spinosa L.). Their result showed that leaching and $1000 \mathrm{ppm} \mathrm{GA}_{3}$ had the most germination. Similar to our result

(18), revealed that caper seeds treated with sulfuric acid for $30 \mathrm{~min}$ and $200-400 \mathrm{ppm}$ $\mathrm{GA}_{3}$, had the most significant percentage germination. Reaching or using sulfuric acid washes Mucilage, ABA and other germination inhibitors in pericarp and testa of the seeds (19). The time of using sulfuric acid is very important because increasing acid time damage to the embryo and decrease percentage germination (20-21). 
LABBAFI M. R., et al.

Our results matched to Bhoyar et al. (4), they declared that seed treatment with sulfuric acid for $40 \mathrm{~min}$ and $\mathrm{GA}_{3} 400 \mathrm{ppm}$ showed the best germination. It is supposed that disruption of seed coat allowed diffusion of oxygen in interaction with both growth regulators positively removed seed dormancy. Our results are in agreement with that researchers (2).
They reported that the seed dormancy is mainly due to the hard seed coat that prevents germination. They observed that when the seeds get in touch with water, mucilage comes into existence on the seed coat and hinders embryo to take $\mathrm{O} 2$, thus preventing germination (4).

Table 2. Seed Germination Percentage and Germination Rate with Dormancy Breaking Treatments for Capparis Spinosa L.

\begin{tabular}{|c|c|c|c|c|c|}
\hline \multirow{2}{*}{$\begin{array}{l}\text { Dormancy breaking treatments } \\
\text { Control }\end{array}$} & \multirow{2}{*}{$\frac{\text { Temperature }}{\text { T20 }}$} & \multicolumn{2}{|c|}{$\begin{array}{c}\text { Germination } \\
\text { percentage }\end{array}$} & \multicolumn{2}{|c|}{$\begin{array}{c}\text { Germination } \\
\text { rate }\end{array}$} \\
\hline & & 23.33 & $\mathrm{~d}-\mathrm{i}$ & 0.380 & $\mathrm{~b}-\mathrm{k}$ \\
\hline $0.1 \% \mathrm{PN}$ & T20 & 10.26 & $\mathrm{~g}-\mathrm{m}$ & 0.343 & b-1 \\
\hline $0.2 \% \mathrm{PN}$ & $\mathrm{T} 20$ & 4 & $1-n$ & 0.162 & $\mathrm{f}-\mathrm{l}$ \\
\hline 500ppm GA 3 & $\mathrm{~T} 20$ & 25 & $\mathrm{c}-\mathrm{h}$ & 0.528 & $b-f$ \\
\hline $1000 \mathrm{ppm} \mathrm{GA} 3$ & $\mathrm{~T} 20$ & 20.59 & $e-j$ & 0.426 & $b-j$ \\
\hline soaking in running water $(24 \mathrm{~h})+1000 \mathrm{ppm} \mathrm{GA} 3$ & $\mathrm{~T} 20$ & 16.66 & $f-1$ & 0.533 & b-g \\
\hline Sulfuric acid $(30 \mathrm{~min})+500 \mathrm{ppm} \mathrm{GA} 3$ & $\mathrm{~T} 20$ & 11.66 & $f-m$ & 0.206 & e-1 \\
\hline Soaking $(24 \mathrm{~h})+1000 \mathrm{ppm} \mathrm{GA}_{3}$ & $\mathrm{~T} 20$ & 15 & $f-m$ & 0.502 & b-h \\
\hline $\begin{array}{l}\text { Sulfuric acid(30 min)+soaking in runner water }(24 \mathrm{~h})+ \\
1000 \mathrm{ppm} \mathrm{GA}\end{array}$ & $\mathrm{T} 20$ & 18.33 & e-k & 0.342 & b-1 \\
\hline Sulfuric acid $(30 \mathrm{~min})+1000 \mathrm{ppm} \mathrm{GA} 3(90 \mathrm{~min})$ & $\mathrm{T} 20$ & 8.33 & $\mathrm{i}-\mathrm{n}$ & 0.265 & $\mathrm{c}-1$ \\
\hline Sulfuric acid $(30 \mathrm{~min})$ & $\mathrm{T} 20$ & 6.66 & h-n & 0.127 & $\mathrm{~g}-1$ \\
\hline Sulfuric acid (60 min) & $\mathrm{T} 20$ & 8.33 & h-n & 0.205 & e-1 \\
\hline Sulfuric acid $(15 \mathrm{~min})+1000 \mathrm{ppm} \mathrm{GA}_{3}$ & $\mathrm{~T} 20, \mathrm{~T} 30$ & 50 & $a-d$ & 0.701 & $\mathrm{~b}$ \\
\hline $\begin{array}{l}\text { Sulfuric acid }(15 \mathrm{~min})+\text { Soaking }(40 \mathrm{c} \text { for } 30 \mathrm{~min})+ \\
\text { 1000ppm } \mathrm{GA}_{3}\end{array}$ & $\mathrm{~T} 20, \mathrm{~T} 30$ & 53.33 & $\mathrm{a}-\mathrm{c}$ & 0.607 & b-d \\
\hline $\begin{array}{l}\text { Sulfuric acid }(15 \mathrm{~min})+\text { Soaking }(40 \mathrm{c} \text { for } 60 \mathrm{~min})+ \\
1000 \mathrm{ppm} \mathrm{GA}_{3}\end{array}$ & $\mathrm{~T} 20, \mathrm{~T} 30$ & 50 & $a-d$ & 0.499 & $g-g$ \\
\hline $\begin{array}{l}\text { Sulfuric acid }(15 \mathrm{~min})+\text { Soaking }(50 \mathrm{c} \text { for } 30 \mathrm{~min})+ \\
1000 \text { ppm } \mathrm{GA}_{3}\end{array}$ & $\mathrm{~T} 20, \mathrm{~T} 30$ & 50.33 & $\mathrm{a}-\mathrm{c}$ & 0.429 & b-g \\
\hline $\begin{array}{l}\text { Sulfuric acid (15 min)+Soaking ( } 60 \mathrm{c} \text { for } 30 \mathrm{~min})+ \\
1000 \mathrm{ppm} \mathrm{GA}\end{array}$ & $\mathrm{T} 20, \mathrm{~T} 30$ & 30 & b-g & 0.351 & b-1 \\
\hline $\begin{array}{l}\text { Sulfuric acid }(15 \mathrm{~min})+\text { Soaking }(70 \mathrm{c} \text { for } 15 \mathrm{~min})+ \\
1000 \text { ppm } \mathrm{GA}_{3}\end{array}$ & T20,T30 & 0 & $\mathrm{n}$ & 0.000 & 1 \\
\hline Sulfuric acid $(15 \mathrm{~min})+2000 \mathrm{ppm} \mathrm{GA}_{3}$ & T20,T30 & 75.92 & a & 1.348 & $\mathrm{a}$ \\
\hline $\begin{array}{l}\text { Sulfuric acid (15 min)+Soaking ( } 40 \mathrm{c} \text { for } 30 \mathrm{~min})+ \\
\text { 2000ppm } \mathrm{GA}_{3}\end{array}$ & T20,T30 & 40 & b-e & 0.654 & b-d \\
\hline $\begin{array}{l}\text { Sulfuric acid }(15 \mathrm{~min})+\text { Soaking }(40 \mathrm{c} \text { for } 60 \mathrm{~min})+ \\
2000 \mathrm{ppm} \mathrm{GA}_{3}\end{array}$ & T20,T30 & 53.33 & $\mathrm{a}-\mathrm{c}$ & 0.658 & $\mathrm{bc}$ \\
\hline $\begin{array}{l}\text { Sulfuric acid (15 min)+Soaking (50 c for } 30 \mathrm{~min})+ \\
\text { 2000ppm } \mathrm{GA}_{3}\end{array}$ & T20,T30 & 60 & $\mathrm{ab}$ & 0.611 & b-d \\
\hline $\begin{array}{l}\text { Sulfuric acid }(15 \mathrm{~min})+\text { Soaking }(60 \mathrm{c} \text { for } 30 \mathrm{~min})+ \\
\text { 2000ppm } \mathrm{GA}_{3}\end{array}$ & $\mathrm{~T} 20, \mathrm{~T} 30$ & 50 & a-d & 0.388 & $\mathrm{~b}-\mathrm{k}$ \\
\hline $\begin{array}{l}\text { Sulfuric acid (15 min)+Soaking ( } 70 \mathrm{c} \text { for } 15 \mathrm{~min})+ \\
\text { 2000ppm } \mathrm{GA}_{3}\end{array}$ & T20,T30 & 6.66 & $\mathrm{k}-\mathrm{n}$ & 0.049 & $\mathrm{j}-\mathrm{l}$ \\
\hline $\begin{array}{l}\text { Control } \\
\text { soaking }(24 \mathrm{~h})\end{array}$ & $\begin{array}{l}\text { T20,T30 } \\
\text { T20,T30 }\end{array}$ & $\begin{array}{l}5 \\
5\end{array}$ & j-n & $\begin{array}{l}0.044 \\
0.044\end{array}$ & $j-1$ \\
\hline soaking $(48 \mathrm{~h})$ & T20,T30 & 13.33 & $f-m$ & 0.116 & $\mathrm{~g}-1$ \\
\hline Sulfuric acid (15 min)+ soaking $(24 \mathrm{~h})$ & $\mathrm{T} 20, \mathrm{~T} 30$ & 1.66 & $\mathrm{mn}$ & 0.015 & $\mathrm{kl}$ \\
\hline Sulfuric acid (15 min)+ soaking $(48 \mathrm{~h})$ & $\mathrm{T} 20, \mathrm{~T} 30$ & 5 & $\mathrm{j}-\mathrm{n}$ & 0.044 & $\mathrm{j}-\mathrm{l}$ \\
\hline soaking $(24 \mathrm{~h})+500 \mathrm{ppm} \mathrm{GA} 3$ & T20,T30 & 20 & $e-j$ & 0.174 & $f-1$ \\
\hline soaking $(24 \mathrm{~h})+1000 \mathrm{ppm} \mathrm{GA}_{3}$ & T20,T30 & 25 & $\mathrm{c}-\mathrm{h}$ & 0.217 & $\mathrm{~d}-1$ \\
\hline Sulfuric acid $(15 \mathrm{~min})+$ soaking $(24 \mathrm{~h})+1000 \mathrm{ppm} \mathrm{GA}_{3}$ & T20,T30 & 33.33 & $b-f$ & 0.290 & b-1 \\
\hline Sulfuric acid $(15 \mathrm{~min})+$ soaking $(48 \mathrm{~h})+1000 \mathrm{ppm} \mathrm{GA}_{3}$ & $\mathrm{~T} 20, \mathrm{~T} 30$ & 33.33 & b-f & 0.290 & $b-1$ \\
\hline Soaking $(48 \mathrm{~h})+20 \mathrm{ppm}$ TDZ & T20,T30 & 8.33 & i-n & 0.073 & i-l \\
\hline Soaking $(48 \mathrm{~h})+20 \mathrm{ppm}$ BAP & $\mathrm{T} 20, \mathrm{~T} 30$ & 10 & $\mathrm{~h}-\mathrm{n}$ & 0.087 & i-l \\
\hline
\end{tabular}


The different letters showed significantly by LSD test at $\mathrm{p}<0.05$

$\mathrm{GA}_{3}$; Gibberellic acid: ‘PN: Potassium nitrate (KNO3) ‘BAD ; Benzyl amino-purine TDZ: Thidiazuron

Results of Sozzi and Chiesa (1995) obtained caper seeds treated with $\mathrm{H}_{2} \mathrm{SO}_{4}$ and $\mathrm{H}_{2} \mathrm{SO}_{4}+$ $\mathrm{GA}_{3}$ had the highest germination. This was in agreement with other work on this species (22).

In others' research, sulfuric acid had the original effect on caper germination (8) and $\mathrm{GA}_{3}$ used for Complementary effect. In this study $\mathrm{GA}_{3} 2000$ ppm had the main effect and sulfuric acid alone no performance on seeds germination. This result in this study may due to $\mathrm{GA}_{3}$ concentration $(2000 \mathrm{ppm})$ is 20 times more than they result.

\section{CONCLUSION}

Sulfuric acid for $15 \mathrm{~min}$ and $2000 \mathrm{ppm} \mathrm{GA}_{3}$ under alternate $20,30 \circ \mathrm{C}$ temperatures were the best method of breaking seed dormancy of caper. Results obtained by treatment clearly suggest that the dormancy of the caper seed is imposed by its covering structures.

\section{REFERENCES}

1. Zohary, M., The speces of Capparis in the Mediterranean and the Near Eastern Countries. Bul. Res. Coun. Israel. 8: 49-64, 1960.

2. Soyler, D. and Khawar, Kh.M., Seed Germination of Caper (Capparis ovata var. Herbacea) Using $\alpha$ Naphthalene Acetic Acid and Gibberellic Acid. International Journal of Agriculture \& Biology. 1(9): 3537, 2007.

3. Güleryüz, M., Özkan, G. and Ercisli, S., Caper (Capparis spp.) Growing Techniques and Economical Importance. 1st International Syposium on Sustainable Development, Sarajevo. P: 94-97, 2009.

4. Bhoyar, M.S., Mishra, G.P., Singh, R. and Singh, S.B., Effects of various dormancy breaking treatments on the germination of wild caper (Capparis spinosa) seeds from the cold arid desert of trans-Himalayas. Indian Journal of Agricultural Sciences. 80 (7): 621-625, 2010.

5. Rao, V.S., Braun, J.W. and Khan, A.A., Promotive effects of organic solvents and kinetin on dark germination of lettuce seeds. Plant. Physiol. 3, 446-449, 1976.

6. Bewley, J.D. and Black, M., Seeds: Physiology of Development and Germination. Plenum Press, New York, 367 pp, 1985.

7. Bewley, J.D., Leung, D.W.M. and Ouellette, F.B., The cooperative role of endo+mannanase, nannosidase and ogalactosidase in the mobilization of endosperm cell wall hemicelhtloses of

germinated lettuce seed. In: C. Nozzolillo, P. Lea and P. Loewus (Editors), Mobilization of Reserves in Germination. Recent. Advances in Phytochemistry, 17. Plenum Press, New York, pp. 137-151, 1983.

8. Sozzi, G. and Chiesa, A. Improvement of caper (Capparis spinosa L.) seed germination by breaking seed coat-induced dormancy. Scientia Horticulturae. 62: 255261, 1995.

9. Olmez, Z., Yahyaoglu, Z. and Ucler, A.O., Effects of $\mathrm{H}_{2} \mathrm{SO}_{4}, \quad \mathrm{KNO}_{3}$ and $\mathrm{GA}_{3}$ treatments on germination of caper (Capparis ovata Desf.) seeds. Pakistan Journal of Biological Sciences. 7(6): 879882, 2004.

10.Fernandez, H., Perez, C., Revilla, M. A. and Perez-Gar-cia, F., The levels of $\mathrm{GA}_{3}$ and $\mathrm{GA}_{20}$ may be associated with dormancy release in Onopordum nervosum seeds. Journal of Plant Growth Regula-tion 38: 141-3, 2002.

11.Pupalla, N. and Fowler, J.I., Lesquerella seed pre-treatment to improve germination. Industrial Crops and Products, 17: 61-69, 2002.

12.Kara, Z., Ecevit, F., Karakaplan, S., Toprak koruma elemani ve yeni bir tarismal urur olarak kapari (Capparis spinosa spp.). Tarim-Cevre Iliskileri Sempozyyumu. Mersin, 919-929, 1996. (In Turkish)

13.Kontaxis, D.G., Caper: Specialty and Minor Crops Handbook. Small Farm Center, University of California, Davis, 1997.

14.Abdelmoumen, H., Missbah, E.L. and Idrissi, M., Germination, growth and nodulation of Trigonella foenum-graecum L. (Fenu Greek) under salt stress. Afr. J. Biotechnol., 8: 2489-2496, 2009.

15.Petropoulos, G.A. Fenugreek; The genus Trigonella. Taylor and Francis, London and New York, p. 105, 2002.

16.Yang, Q.H., Ye, W.H. and Yin, X.J., Dormancy and germination of Areca triandra seeds. Scientia Horticulturae, 113: 107-111, 2007.

17.Farhoudi, R. and Makezadeh Tafti, M., The Effect of Seed Dormancy Breaking Methods on Caper (Capparis spinosa L.) Germination and Growth. Scientific Journal of Agronomy and Plant Breeding. 1(1): 2025, 2013.

18.Bahrani, M.J., Ramazani Gask, M., Shekafandeh A. and Taghvaei, M., Seed germination of wild caper (Capparis spinosa L., var. parviflora) as affected by dormancy breaking treatments and salinity 
levels. J. Environ. Experimental Bot. 36(3):776-780, 2008.

19. Yambe, Y., Hori, Y. and Takeno, K., Levels of endogenous ABA in Rose achenes and leaching with activated charcoal to improve seed germination. $J$. Japan Horticultural Sci. 61(2): 383-387, 1992.

20.Lyons, J., Graham, D. and Raison, J., Low Temperature Stress in Crop Plants. Academic Press. New York 360p, 1979.

\section{LABBAFI M. R., et al.}

21.Bahrani. M.J. and Niknejad-Kazempour, H., Effects of dormancy breaking treatments and salinity on seed germination of two desert shrubs. Arid Land Research and Management. 21: 107-118, 2007.

22. Orphanos, P.I., Germination of caper (Capparis spinosa L.) seeds. J. Hortic. Sci. 58: 267-270, 1983. 